\title{
Cytotoxicity, Genotoxicity, and Phytotoxicity of Tannery Effluent Discharged into Palar River Basin, Tamil Nadu, India
}

\author{
Suki Roy, Lubbnaz Nagarchi, Ishita Das, \\ Jayasri Mangalam Achuthananthan, and Suthindhiran Krishnamurthy \\ Marine Biotechnology and Bioproducts Lab, School of Biosciences and Technology, VIT University, Vellore 632014, India \\ Correspondence should be addressed to Suthindhiran Krishnamurthy; ksuthindhiran@vit.ac.in
}

Received 15 September 2015; Revised 22 November 2015; Accepted 30 November 2015

Academic Editor: Cinta Porte

Copyright (c) 2015 Suki Roy et al. This is an open access article distributed under the Creative Commons Attribution License, which permits unrestricted use, distribution, and reproduction in any medium, provided the original work is properly cited.

\begin{abstract}
Ambur, a town located on the banks of Palar River, is considered one of the most polluted areas in India and occupied by hundreds of tanneries and leather product units. The present study was designed to evaluate the toxic effect of discharged tannery effluent (TE) on model agricultural crops, ecofriendly microorganisms, and human blood cells. The phytotoxic effects of TE tested on Allium cepa and Lemna minor revealed inhibition of root growth and significant reduction in number of fronds, protein, and chlorophyll content. Moreover, TE induced chlorosis and tissue necrosis in Nostoc muscorum at low concentration (10\%). TE has also negative impact on ecofriendly microorganisms, Bacillus thuringiensis, Rhizobium etli, and Aspergillus terreus which play an important role in the nutrition of plant growth. The genotoxicity of TE was investigated in human leukocytes which showed interference with normal mitotic division with subsequent cell lysis. It also intervened with the normal replication process and induced micronucleus formation in the healthy leukocyte. $5 \%$ concentration of TE has been revealed to be toxic to erythrocytes. From this study TE found in the Palar River of Ambur has adverse effects on all the three levels of organisms in ecosystem even at lower concentrations.
\end{abstract}

\section{Background}

Indiscriminate discharge of untreated waste water directly or indirectly into aquatic bodies may result in polluted water resources. This would adversely affect humans and other living systems. In some regions, the environment is under increasing pressure from solid and liquid wastes emanating from the leather industry. Tannery effluents are ranked as the highest pollutants among all industrial wastes [1]. India is the third largest producer of leather in the world having about 3000 tanneries with annual processing capacity of 0.7 million tonnes of hides and skin [2]. The metals generally present in tannery effluents (chromium, aluminium, zirconium, etc.) are all classified as having a high/moderately acute or chronic toxic effect on organic life [3]. These are inevitable byproducts of the leather manufacturing process and cause significant pollution unless treated in some way prior to discharge. Moreover, the leather industry mainly causes high influx of chromium into the biosphere which contributes $40 \%$ of the total industrial use. Treated wastewater discharged from tanning industries contains high level of biochemical oxygen demand (BOD), chemical oxygen demand (COD), electrical conductivity, and heavy metals especially $\mathrm{Cr}$ above permissible levels making it potentially toxic [4].

The Palar River is one of the major rivers flowing through Vellore district $(120 \mathrm{~km}$ in length with 4710 area of river basin). The Palar valley, one of the most desirable locations of tanning industry in India, is located near Ambur, India. There was a linear growth of tanning industry in Palar valley as well as the waste discharged to the river. The chemicals released by the leather tanneries directly make way into Palar River (perennial stream that is often completely dry) and traversing across Ambur has led to ground water pollution thereby disturbing the ecological balance [5].

Elevated chromium concentration in the effluents from tanneries poses a serious environmental concern in Vellore district. Depending on its oxidation state and concentrations, chromium can be either beneficial or toxic to animals, plants, and humans [6]. Cr (III) is considered an essential component of a balanced human and animal diet for preventing 
adverse effects in the metabolism of glucose and lipids [7]. High concentrations of tannery effluent can interfere with several metabolic processes because of its ability to coordinate various organic compounds resulting in inhibition of metalloenzyme systems [8]. The presence of heavy metals in tannery effluent causes toxic effect to living organisms as reported by Siyanbola et al. (2011) [9]. The toxic metals in tannery effluent cause lethal effects, genotoxicity, mutagenicity, and carcinogenicity to microorganisms, aquatic organisms, plants, animals, and human beings [10].

To identify the key toxic compounds and underlying toxic potential of the compounds present in tannery effluent, various toxicity assays should be performed. The present study was to evaluate the toxic effect of tannery effluent on microorganisms (Bacillus, Rhizobium, and Aspergillus), Cyanobacterium (Nostoc muscorum), plants (Allium cepa, Lemna minor), and red blood cells (RBC).

\section{Materials and Methods}

2.1. Study Area and Effluent Collection. The effluent sample was collected from highly contaminated tannery effluent discharge site in Palar River basin with geographical location of $12.78^{\circ} \mathrm{N}$ latitude $78.7^{\circ} \mathrm{E}$ longitude. Sample sites were wellknown for their high pollution rate for the past 25 years and before that this basin was agricultural field. For the last 25 years, effluents from most of the leather industries are being discharged into the river, road sides, and agricultural fields. Effluent sample was collected in acid washed sterile plastic containers of 5-litre capacity from the TE accumulated site. The collected samples were transported to the laboratory aseptically and stored in sterile condition until further experiments were conducted.

2.2. Physicochemical Properties of Effluent. The collected sample was analyzed for a number of physicochemical parameters such as colour, $\mathrm{pH}$, total dissolved solids (TDS), and total solids (TS) employing standard methods. Determination of BOD (biochemical oxygen demand) was done by Winkler's iodometric method [11] and COD (chemical oxygen demand) was determined after oxidation of organic matter in strong tetraoxosulphate VI acid medium by $\mathrm{K}_{2} \mathrm{Cr}_{2} \mathrm{O}_{7}$ at $148^{\circ} \mathrm{C}$, with back titration (titrimetric method) [12]. The dissolved oxygen (DO) content was determined before and after incubation. The chromium, zinc, nickel, lead, and magnesium content were estimated by atomic absorption spectrophotometer and identified by limit test (http://www .epa.gov/). Sodium and potassium content was measured by flame photometric method [13]. $\mathrm{PO}_{4}, \mathrm{NO}_{2}, \mathrm{NO}_{3}$, and chlorine were determined by ion chromatography [14].

2.3. Microbiological Activity of Tannery Effluent. The minimum inhibitory concentration (MIC) of TE for each microorganism (Bacillus thuringiensis, Rhizobium etli, and Aspergillus terreus) was determined. Pure culture Bacillus thuringiensis was cultured in Mueller-Hinton broth, Rhizobium etli in PY rich medium $[15,16]$, and Aspergillus terreus in potato dextrose broth medium. The test microorganisms were obtained from Marine Biotechnology and Bioproducts
Lab, VIT University, Vellore, and were cultured overnight in respective media prior to the experiment. The zone of inhibition of tannery effluent was determined by Kirby-Bauer well diffusion method [17]. The test microorganisms were plated and different concentrations of tannery effluent were added to the wells. The zone of inhibition was observed after 48 hours of incubation. To detect the MIC the collected TE was diluted with respective media and $100 \mu \mathrm{L}$ of the TE of various concentrations (0-100\%) was added to each well of 96-well microplate and test organisms were inoculated. This was allowed for incubation at $28^{\circ} \mathrm{C}$ for $24-72 \mathrm{hrs}$ and optical density (OD) was measured at $595 \mathrm{~nm}$. The lowest concentration of tannery effluent that inhibits the growth of microorganisms was considered the minimum inhibitory concentration (MIC) of TE against the organism tested [18]. Distilled water was used as control and the experiments were done in triplicates.

2.4. Toxicity Assessment Using Cyanobacteria. Nostoc muscorum was used for cyanobacterial bioassay. Nostoc muscorum was grown in flask containing $200 \mathrm{~mL}$ of nitrogenfree modified Chu-10 medium [19]. Culture was aerated 2-3 times per days. The cells in log phase (4-6-day-old culture) were added to four different dilutions of TE $(0,25,50$, and $100 \%)$. Samples were incubated and cells were harvested after $7-8$ days by centrifugation at $10000 \mathrm{rpm}$ for $30 \mathrm{~min}$ at $4^{\circ} \mathrm{C}$ [20]. Samples were examined for different growth parameters, such as total chlorophyll content and protein content by spectrophotometric and fluorometric method. Protein content was analyzed as described earlier [21]. The experiments were performed in triplicates.

2.5. Cultivation of Allium cepa. Healthy onion bulbs of Allium сера were purchased from local supermarket and washed in running water to remove contamination on outer covering. After drying onion bulbs (1.5 to $2.2 \mathrm{~cm}$ in diameter) were rinsed thoroughly with tap water and the outer scales were removed. Old root remnants were removed without disturbing the root primordia. Initially the onions were grown in distilled water for $24 \mathrm{hrs}$ and then the actively dividing root tip cells of onion were exposed to different TE concentrations $(5,10,15,20,25,30,35,40,45,50$, and 55\%) along with a control (distilled water). Each concentration was set up in three replicates. Every 24 hours the test solutions are replaced by fresh ones. The plants were harvested after $48 \mathrm{hr}$ to evaluate the phytotoxic effects. The root length of Allium cepa, grown at different concentrations of TE, was measured with the help of a meter scale and mean root length was calculated. Minimum root inhibition was calculated as $\mathrm{EC}_{50}$.

2.6. Cultivation of Lemna minor. Fresh duck weeds (Lemna minor L.) were collected from Department of Horticulture at VIT University and the assay was performed at room temperature. The fronds were separated carefully and disinfected with $1 \%$ of sodium hypochlorite solution. About 2 grams of fronds was then inoculated in Quarter Coic and Lessaint solution $[22,23]$ along with TE $(5 \%, 10 \%, 15 \%$, and $25 \%)$ for $96 \mathrm{hrs}$. The medium without TE served as control. 
2.7. Protein Extraction. Total soluble proteins were determined according to Lowry's method. This is done by collecting the TE treated fronds from each test concentration and by grinding using pestle and mortar in $5 \mathrm{~mL}$ of potassium phosphate buffer. The tubes were centrifuged at 12,000 rpm for $20 \mathrm{~min}$. The clear supernatant was collected and the total protein content was estimated by Lowry's method [21].

\subsection{Determination of Photosynthetic Pigments and Soluble} Protein. Approximately $150 \mathrm{mg}$ of Lemna fronds treated with different TE concentrations were homogenized on ice in $3 \mathrm{~mL}$ of $66 \mathrm{mM}$ phosphate buffer ( $\mathrm{pH} 7.2$ ) by adding $10 \mathrm{mM} \mathrm{KCl}$ sequentially. The homogenate was extracted with $80 \%$ cold acetone and stored for standardization. Chlorophyll content was determined by the method of Arnon (1949) [24]. The absorbance of pigment extract was measured at wavelength of $470,537,647,663$, and $730 \mathrm{~nm}$ using UV-Vis spectrophotometer. The contents of chlorophyll a, chlorophyll b, and carotenoid were calculated in accordance with experimental equations as described by Arnon (1949) [24].

\subsection{Genotoxicity Analysis Using Leucocytes}

2.9.1. Determination of Chromosomal Abnormality. Heparinized peripheral blood obtained from a healthy nonsmoking donor was used for all the experiments. About $5 \mathrm{~mL}$ of venous blood sample from healthy donor $(\mathrm{O}+\mathrm{ve})$ was collected. Five vials each containing $0.5 \mathrm{~mL}$ of blood were inoculated in $5 \mathrm{~mL}$ of RPMI 1640 medium (Himedia, India) supplemented with $20 \%$ of fetal bovine serum, $100 \mathrm{IU} / \mathrm{mL}$ penicillin, $100 \mu \mathrm{g} / \mathrm{mL}$ streptomycin, $0.5 \mathrm{mg} / \mathrm{mL}$ L-glutamine, and $6 \mu \mathrm{g} / \mathrm{mL}$ of phytohemagglutinin (PHA) which were added under aseptic condition. The culture vials were incubated at $37^{\circ} \mathrm{C}$ for 72 hours. The cultures were shaken every 24 th hour and carbon dioxide was released once in 24 hours. At the 48th hour of incubation, the cultures were treated with TE (5\%, 10\%, 15\%, and 20\%) and incubated for the next 24 hours at $37^{\circ} \mathrm{C}$. A positive control with mitomycin-C and a control without tannery effluent were maintained. After $70 \mathrm{hrs}$ the dividing cells were arrested at metaphase by adding 2 drops of $0.1 \%$ colchicine (Sigma, India) and incubated further for 2 hrs. After 72 hrs of incubation the cells were centrifuged, the supernatant was gently discarded, and $6 \mathrm{~mL}$ of prewarmed hypotonic solution ( $\mathrm{KCl} 0.075 \mathrm{M}$ ) was added to swell the cells. After incubation, the contents were centrifuged at $2000 \mathrm{rpm}$ for five minutes and supernatant was discarded, treated twice with Carnoy's fixative ( $3: 1$ ratio of methanol:acetic acid), and mixed vigorously. After fixation all the contents were centrifuged and supernatant was discarded and washing step was continued till the pellet turned white. The slides were prepared and kept in incubator at $37^{\circ} \mathrm{C}$ for drying. Later, the slides were stained with $10 \%$ Giemsa stain and destained with deionised water [25-27].

2.9.2. Cell Counting. The cells were counted in every vial using haemocytometer by staining the cells with Trypan blue (Himedia, India). The estimations were made by scoring the cells in duplicates for each concentration.
2.9.3. Micronuclei Detection. For micronuclei detection, $0.5 \mathrm{~mL}$ of blood was added to $5 \mathrm{~mL}$ of RPMI-1640 medium supplemented with $15 \%$ of fetal bovine serum (FBS). The five vials of lymphocyte culture were incubated for 72 hours at $37^{\circ} \mathrm{C}$. The cultures were shaken every 24 th hour and carbon dioxide was released. At the 24th hour of the experiment different concentrations $(5 \%, 10 \%, 15 \%$, and $20 \%)$ of tannery effluent were added and a control (without tannery effluent) was also maintained. For micronucleus preparation cytochalasin B (Sigma, India) was added to each vial at a final concentration of $4 \mu \mathrm{g} / \mathrm{mL}$ after 44 hours after culture initiation [28-30]. The vials were kept for incubation for another $24 \mathrm{hrs}$ at $37^{\circ} \mathrm{C}$ and subjected to a brief cold hypotonic $(0.056 \%)$ $\mathrm{KCl}$ treatment. Micronucleus slides were made by fixation in methanol:acetic acid $(3: 1)$ and the slides were further stained using 2\% alkaline Giemsa. The cells were observed under light microscope and binucleated cells were scored for each.

2.9.4. In Vitro Hemolytic Assay. In vitro haemolytic activity was analyzed as described by Suthindhiran and Kannabiran (2009) [31]. Human erythrocytes were prepared from the peripheral blood $(\mathrm{A}+)$ of a healthy volunteer. About $5 \mathrm{~mL}$ of blood was collected in a heparinized tube and $2 \%$ erythrocyte suspension was prepared by washing the cells three times with $20 \mathrm{mM}$ Tris- $\mathrm{HCl}$ containing $25 \mathrm{mM} \mathrm{NaCl}$ (pH 7.4). The cells were further washed three times in nine volumes of sterile $0.9 \%$ saline solution. After each washing, cells were centrifuged at $2000 \mathrm{rpm}$ for $5 \mathrm{~min}$ and the supernatant was discarded. The final pellet was diluted to $1 / 9(\mathrm{v} / \mathrm{v})$ in sterile $0.9 \%$ $\mathrm{NaCl}$ saline solution then to $1 / 24(\mathrm{v} / \mathrm{v})$ in sterile Dulbecco's phosphate buffer saline ( $\mathrm{pH} 7.0$ ) containing $0.5 \mathrm{mM}$ boric acid and $1 \mathrm{mM}$ calcium chloride [32]. The test was carried out in 96 -well plate. To each well $100 \mu \mathrm{L}$ of $0.85 \%$ sodium chloride solution containing $10 \mathrm{mM}$ calcium chloride was added. To this $100 \mu \mathrm{L}$ of tannery effluent in different concentrations (5\%, $10 \%, 15 \%$, and $20 \%$ ) was added. $100 \mu \mathrm{L}$ of $2 \%$ erythrocyte suspension was added to each well and incubated at room temperature for $30 \mathrm{~min}$. The contents were then centrifuged and absorbance of the supernatant was measured at $540 \mathrm{~nm}$ against a reagent blank in which the effluent was substituted by saline. $20 \mathrm{~mL}$ of $0.1 \%$ Triton X-100 in $0.85 \%$ saline served as positive control and negative control contained distilled water. The percentage of hemolysis was calculated [33] and the average value was calculated from triplicate assay.

\section{Results}

3.1. Physicochemical Characteristics of Tannery Effluent. The colour of the effluent appeared as dark brown with $\mathrm{pH}$ of 7.6 (Table 1). The biological oxygen demand (BOD) and the chemical oxygen demand (COD) of the effluent were found to be $526 \mathrm{mg} / \mathrm{L}$ and $2986 \mathrm{mg} / \mathrm{L}$, respectively. Dissolved oxygen values of the effluent were measured as $36.21 \mathrm{mg} / \mathrm{L}$. The effluent had high total dissolved solids (TDS) which was about $6395 \mathrm{mg} / \mathrm{L}$. The data represented in Table 2 showed higher values of metals and anions in the effluent than the recommended values. The effluent was found to have lead, iron, copper, zinc, manganese, and arsenic concentrations much 
TABLE 1: Physicochemical characteristics of the tannery effluent collected from Palar River (all values are mean range for three observations each).

\begin{tabular}{lcc}
\hline Sr. number & Parameter & Tannery effluent (values) \\
\hline 1 & Colour & Dark brown \\
2 & pH & 7.6 \\
3 & BOD & $526 \mathrm{mg} / \mathrm{L}$ \\
4 & COD & $2985 \mathrm{mg} / \mathrm{L}$ \\
5 & DO & $36.21 \mathrm{mg} / \mathrm{L}$ \\
6 & TDS & $6395 \mathrm{mg} / \mathrm{L}$ \\
\hline
\end{tabular}

TABLE 2: Average concentration of metals and anions in the tannery effluent collected from Palar River (all values are mean range for three observations each).

\begin{tabular}{lccc}
\hline Sr. number & Metals & $\begin{array}{c}\text { Concentration } \\
\text { in tannery } \\
\text { effluent }(\mathrm{mg} / \mathrm{L})\end{array}$ & $\begin{array}{c}\text { USEPA } \\
\text { guidelines } \\
(\mathrm{mg} / \mathrm{L})\end{array}$ \\
\hline 1 & Lead & 2.98 & 0.2 \\
2 & Iron & 5.21 & 0.3 \\
3 & Cobalt & 3.83 & 0.03 \\
4 & Copper & 3.12 & 1.0 \\
5 & Zinc & 5.73 & 1.0 \\
6 & Manganese & 4.11 & 1.0 \\
7 & Chromium & 9.21 & 0.1 \\
8 & Nickel & 11.79 & 0.1 \\
9 & Arsenic & 1.46 & 0.05 \\
10 & Magnesium & 3.87 & 1.0 \\
11 & Cadmium & 2.26 & 0.1 \\
12 & Nitrate & 78 & 50 \\
13 & Nitrite & 129 & 12 \\
14 & Phosphate & 16.9 & 5 \\
15 & Sulphate & 776 & 250 \\
16 & Chloride & 187 & 200 \\
\hline
\end{tabular}

higher than regulatory limits set by the US Environmental Protection Agency [34]. The concentration of chromium and nickel in the effluent was at highest levels. In general, the trend of metal availability in the effluent sample was $\mathrm{Ni}>$ $\mathrm{Cr}>\mathrm{Zn}>\mathrm{Fe}>\mathrm{Mn}>\mathrm{Mg}>\mathrm{Co}>\mathrm{Cu}>\mathrm{Pb}>\mathrm{Cd}>\mathrm{Ar}$. The tannery effluent also had higher load of sulphate and chloride of around $776 \mathrm{mg} / \mathrm{L}$ and $187 \mathrm{mg} / \mathrm{L}$, respectively.

3.2. Effect of Tannery Effluent on Microorganisms. Growth of all the tested microorganism (Bacillus thuringiensis, Rhizobium etli, and Aspergillus terreus) were inhibited by TE. The inhibition of growth was observed in bacteria and fungi at a concentration of $30 \%$. The results showed a concentration dependent growth inhibition and zone of inhibition of each organism was determined as shown in Figure 3. The cyanobacterial bioassay indicated that, with increase in concentration of TE, chlorophyll content of the Nostoc muscorum significantly decreased as shown in Table 5. Among all parameters chlorophyll was found to be the most
TABLE 3: Effect of tannery effluent on root growth in Allium cepa (all values are mean $\pm \mathrm{SD}$ range for three observations each). The $\mathrm{EC}_{50}$ was found to be $7.79 \%$.

\begin{tabular}{lcc}
\hline $\begin{array}{l}\text { Concentration of } \\
\text { tannery effluent }(\%)\end{array}$ & Root length $(\mathrm{cm})$ & Root growth (\%) \\
\hline 0 & $5.5 \pm 0.33$ & 100 \\
5 & $2.9 \pm 0.27$ & 52.7 \\
10 & $2.6 \pm 0.21$ & 47.2 \\
15 & $2.4 \pm 0.29$ & 43.6 \\
20 & $2.1 \pm 0.27$ & 38.1 \\
25 & $1.5 \pm 0.21$ & 27.2 \\
30 & $0.9 \pm 0.28$ & 16.3 \\
35 & $0.5 \pm 0.31$ & 9.1 \\
40 & $0.2 \pm 0.27$ & 3.6 \\
45 & 0 & 0 \\
50 & 0 & 0 \\
55 & 0 & 0 \\
\hline
\end{tabular}

TABLE 4: Effect of tannery effluent on number of fronds in Lemna minor (all values are mean range for three observations each).

\begin{tabular}{lcc}
\hline $\begin{array}{l}\text { Concentration of } \\
\text { tannery effluent (\%) }\end{array}$ & \multicolumn{2}{c}{ Number of fronds } \\
\hline 0 & 42 & 96 hour \\
5 & 42 & 56 \\
10 & 42 & 38 \\
15 & 42 & 33 \\
20 & 42 & 22 \\
\hline
\end{tabular}

sensitive as it showed chlorosis followed by tissue necrosis even at low concentration (10\%) of TE.

3.3. Effect of Tannery Effluent on Allium cepa and Lemna minor. The root growth inhibition in Allium cepa has been observed at different concentrations of effluent (Table 3). The root growth of the Alium cepa is inhibited by TE even at lower concentrations. The reduction in root length implies inhibition of root growth. About $47.3 \%$ reduction in root growth was observed at lower concentration of TE (5\%). The percentage root growth was found to decrease $(52.7,47.2,43.6$, $38.1,27.2,16.3,9.1$, and $3.6 \%$ ) when the concentration of TE increased $(5,10,15,20,25,30,35$, and 40$)$. Treatment with TE showed significant inhibition of root growth and no root growth was observed in Allium cepa treated with tannery effluent concentration beyond $40 \%$ (Table 3). The $\mathrm{EC}_{50}$ (the concentration of effluent causing $50 \%$ of total damage) of Allium cepa treated with tannery effluent was found to be $7.79 \%$.

Different concentrations of tannery effluent affected the number of fronds in Lemna minor (Table 4). The control showed an increase in the number of fronds after 96 hours of exposure to tannery effluents but all the tannery effluent treated Lemna minor showed significant decrease in the number of fronds in same time period. The number of fronds of Lemna minor treated with lowest concentration of TE (5\%) 
TABLE 5: Effect of tannery effluent on protein content and photosynthetic pigments of Lemna minor (all values are mean \pm SD range for three observations each).

\begin{tabular}{lcccc}
\hline $\begin{array}{l}\text { Concentration } \\
\text { of tannery } \\
\text { effluent }(\%)\end{array}$ & $\begin{array}{c}\text { Protein } \\
\text { concentration } \\
(\mu \mathrm{g} / \mathrm{mL})\end{array}$ & $\begin{array}{c}\text { Chlorophyll a } \\
\text { concentration } \\
(\mu \mathrm{g} / \mathrm{mL})\end{array}$ & $\begin{array}{c}\text { Chlorophyll b } \\
\text { concentration } \\
(\mu \mathrm{g} / \mathrm{mL})\end{array}$ & $\begin{array}{c}\text { Carotenoids } \\
\text { concentration } \\
(\mu \mathrm{g} / \mathrm{mL})\end{array}$ \\
\hline 0 & $60 \pm 0.30$ & $6.687 \pm 0.14$ & $1.00 \pm 0.40$ & $3.474 \pm 0.22$ \\
5 & $52 \pm 0.26$ & $5.79 \pm 0.17$ & $0.916 \pm 0.30$ & $2.95 \pm 0.27$ \\
10 & $50 \pm 0.28$ & $0.907 \pm 0.15$ & $0.811 \pm 0.10$ & $1.946 \pm 0.24$ \\
15 & $38 \pm 0.29$ & $0.738 \pm 0.16$ & $0.800 \pm 0.22$ & $1.044 \pm 0.26$ \\
20 & $12 \pm 0.27$ & $0.636 \pm 0.18$ & $0.640 \pm 0.20$ & $0.360 \pm 0.25$ \\
\hline
\end{tabular}

reduced from 42 to 38 ( $9 \%$ reduction) whereas the exposure of highest concentration of TE (20\%) caused a reduction of $57 \%$ after 96 hours. The control showed a 32\% increase in number of fronds. Some of the effluent treated Lemna minor found to have lost its natural green colour and turned white which indicated the death of fronds and chlorosis.

The protein content and photosynthetic pigments of Lemna minor were affected by tannery effluent (Table 5). The protein content reduced to $52 \mu \mathrm{g} / \mathrm{mL}, 50 \mu \mathrm{g} / \mathrm{mL}, 38 \mu \mathrm{g} / \mathrm{mL}$, and $12 \mu \mathrm{g} / \mathrm{mL}$ with tannery effluent concentration of $5 \%, 10 \%$, $15 \%$, and $20 \%$, respectively. The reduction in protein content was more at the highest concentration of tannery effluent $(20 \%)$. The chlorophyll a and carotenoid content also declined considerably in all concentrations of tannery effluent except the lower concentration (5\%), which showed only a slight decrease. The chlorophyll a content was $86 \%$ retained after treating with $5 \%$ TE but only $9.5 \%$ of chlorophyll a was present after exposing to $20 \%$ TE. The carotenoid concentration of control was estimated to be $3.474 \mu \mathrm{g} / \mathrm{mL}$. The pigment content showed $15 \%$ decrease at the lowest TE concentration (5\%). The increase in TE concentration continued to decrease the carotenoid content in which the highest concentration of TE (20\%) showed 90\% decrease in carotenoid. However, the chlorophyll b content decreased only in higher concentration of tannery effluent. The highest concentration of TE (20\%) showed a 36\% decline in chlorophyll b content whereas exposure with lower concentrations of TE caused only slight decrease.

\subsection{Effect of Tannery Effluent on Human Blood Cells}

3.4.1. Cell Viability. The number of viable cells was found to be $6.25 \times 10^{6}$ in the control. Progressive decrease in cell number from $5.5 \times 10^{6}(5 \% \mathrm{TE})$ to $1.8 \times 10^{5}(20 \% \mathrm{TE})$ was observed with increased exposure to TE. Significant decrease in cell count was found at $15 \%$ and $20 \%$ of TE treated with culture (Table 6). The cell population at these volumes was found be to almost half of the control cell population.

3.4.2. Chromosomal Aberrations. Normal chromosomes were observed in control. However, in chromosomes of TE treated cells, aberrations were observed. Among 50 metaphases counted at least one deletion was observed in one of the chromosomes which were treated with $20 \%$ of TE. At least three types of structural aberrations, namely, chromosome
TABLE 6: Effect of tannery effluent on leukocytecell viability.

\begin{tabular}{lc}
\hline $\begin{array}{l}\text { Volume of tannery effluent } \\
\text { in culture }(\%)\end{array}$ & $\begin{array}{c}\text { Number of cells viable after } \\
\text { treatment }(\text { cells/mL) }\end{array}$ \\
\hline Control & $1.25 \pm 0.01 \times 10^{6}$ \\
5 & $1.1 \pm 0.05 \times 10^{6}$ \\
10 & $8 \pm 1.15 \times 10^{5}$ \\
15 & $7.7 \pm 0.67 \times 10^{4}$ \\
20 & $3.7 \pm 0.29 \times 10^{4}$ \\
\hline
\end{tabular}

breaks (Figure 1(b)), chromosomal gaps (Figure 1(c)), and chromatid gaps (Figure 1(d)), were observed in cells treated with $20 \%$ TE. Fragmentation of the chromosomes in cultures with $10 \%, 15 \%$, and $20 \%$ was also observed.

3.4.3. Micronuclei Detection. Micronuclei were found in the cells obtained from the cultures containing $15 \%$ and $20 \%$ of TE. Micronucleus was found adjacent to the nucleus but was smaller in size than the nucleus. In control the micronucleus was found to be absent. Presence of the micronucleus is an indication of cellular damage; hence, TE is found to induce toxicity to human leukocyte and induces damage in the cells at a concentration of $15 \%$ and $20 \%$, respectively (Table 6).

In Vitro Hemolytic Assay. Hemolysis was observed in cultures treated with TE and was found to be dose dependent. Moderate hemolysis was found at $5 \%$ of TE but significant decrease in erythrocyte population was observed at $10 \%$. The positive control showed $94 \%$ of hemolysis as compared to the tannery effluent. Furthermore, considerable amount of hemolysis was observed at $15 \%$ of TE in which the effluent present in the culture induced cell death of approximately $50 \%$ of erythrocyte population (Figure 2). Hence, $20 \%$ and above of tannery effluent was found to be highly toxic to human erythrocyte.

\section{Discussion}

Overall data emphasize on the inhibitory and toxic effect of TE on plants, human blood cells, and microorganisms. The biological oxygen demand (BOD) values of the effluent were higher than the recommended acceptance level set by Federal Environmental Protection Agency (FEPA) [35] for the discharged effluents of tanneries and textile into water bodies $(50 \mathrm{mg} / \mathrm{L})$. The COD of the effluent was also found 


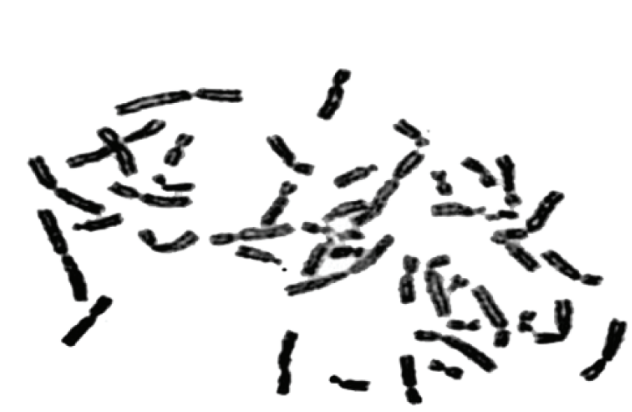

(a)

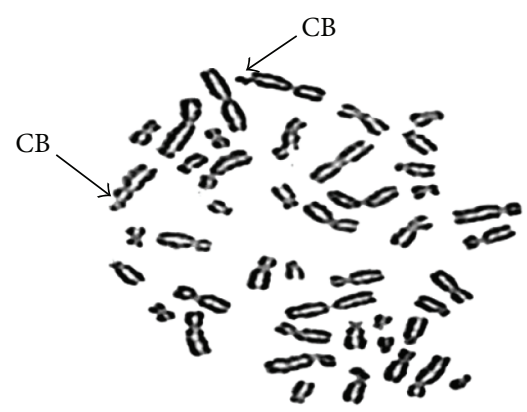

(b)

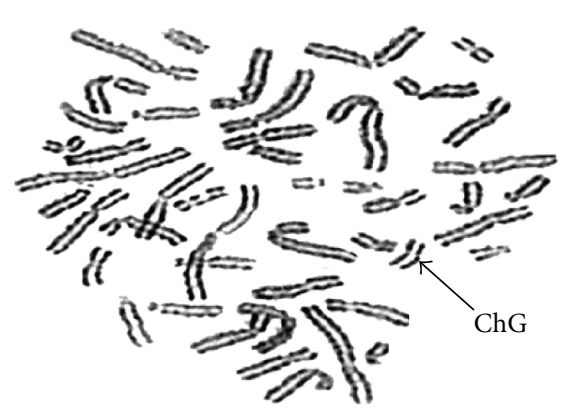

(c)

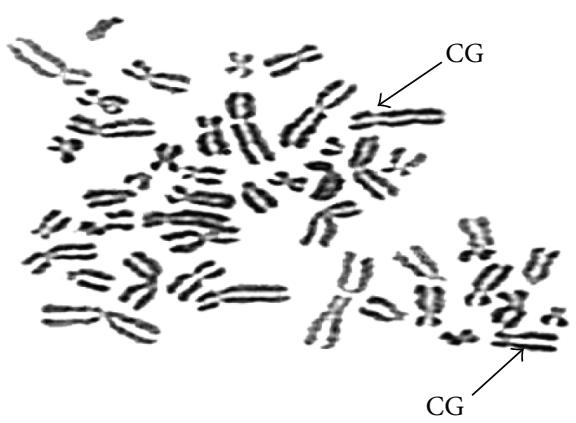

(d)

Figure 1: Chromosomal aberrations in human blood cells due to tannery effluent exposure: (a) Control; (b) human blood cells treated with $20 \%$ TE; arrow indicates chromatid breaks (CB); (c) human blood cells treated with 20\% TE; arrow indicates chromatid gaps (ChG); (d) human blood cells treated with $20 \%$ TE; arrow indicates chromosomal gaps (CG).

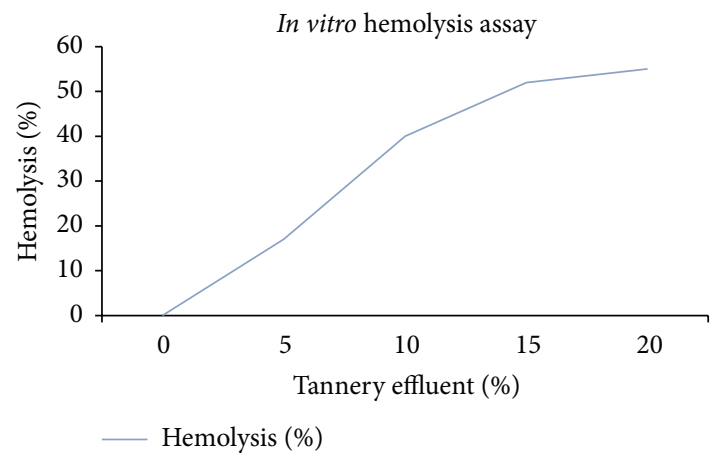

FIgURe 2: Percentage of hemolysis in In vitro Hemolytic Assay indicating the concentration of tannery effluent that can cause $50 \%$ of hemolysis.

to be higher than United States Environmental Protection Agency (USEPA) standard (1000 mg/L) for discharge of TE into surface water [34]. These high levels of BOD and COD values observed in the effluent were due to high quantity of organic matter from a variety of chemicals used in the soaking, tanning, and posttanning processing of leather. It has been reported that only about $20 \%$ of the chemicals used in the tanning method is absorbed by leather and the rest is unconfined as waste thereby raising the levels of BOD in the effluent [36]. It should be noted that high BOD levels in tannery effluent could even cause rapid depletion of dissolved oxygen if directly discharged into surface water. Dissolved oxygen values were relatively less in the analyzed sample due to the increase of organic matter. Total dissolved solids (TDS) were higher than standard value recommended by USEPA [33]. High TDS detected could be credited to the strong colour (from the a range of dying stuff being used in the tannery mills) and they might be the main sources of the heavy metals as higher heavy metals concentrations in river sediments could raise suspended solids concentrations [37]. Any increase in free ion concentrations in the outside surroundings as well as concentrations of other environmental stressors would lead to osmoregulation imbalances in aquatic animals such as fishes. In our study high concentration of heavy metals was observed in the TE. All the values of metals and anions in the effluent were higher than USEPA standard which might be due to the chemicals used by tanneries for chrome tanning process [34]. The concentration of other anions also was found to be higher than USEPA standard values [34]. The high levels of nitrate and nitrite in the TE might be due to the chemicals used in the tanning process which contains nitrogen as element and the nitrogen content in proteinaceous substance [38]. The high level of sulphate was observed in the effluent because of the use of sulphuric acid or product with high sodium sulphate content during tanning process [39].

Higher concentration of TE leads to phytogenic toxicity in tested plants. The main symptoms of the toxicity include reduction in root length, leaf chlorosis, inhibition of seed germination, and depressed biomass [4]. The effect of collected TE on Allium cepa showed a significant reduction in root length, decrease in dry weight, increase in root diameter, and increase in root hairs. The estimated $\mathrm{EC}_{50}$ value of 


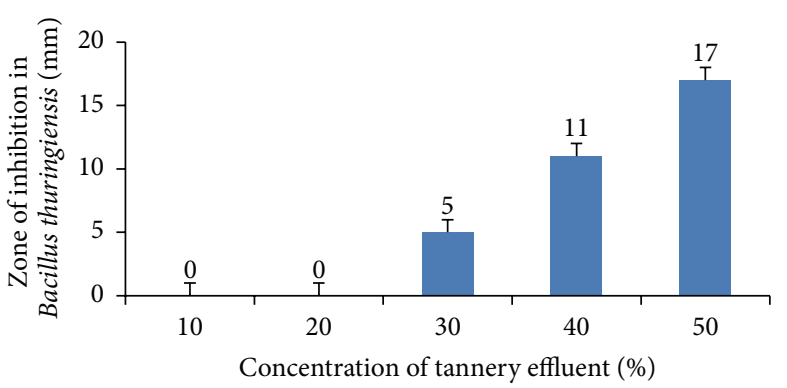

(a)

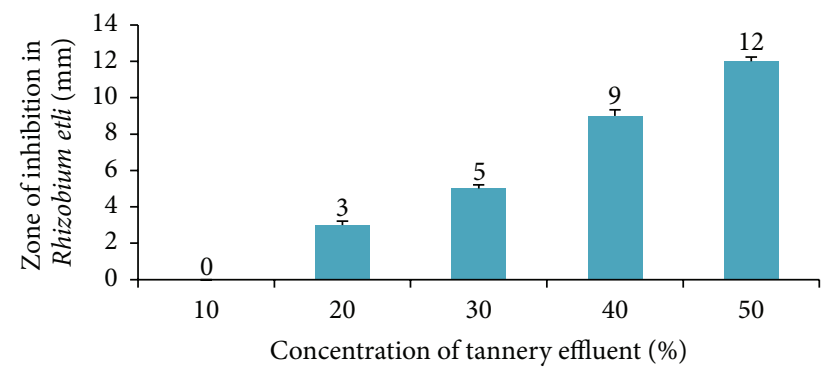

(b)

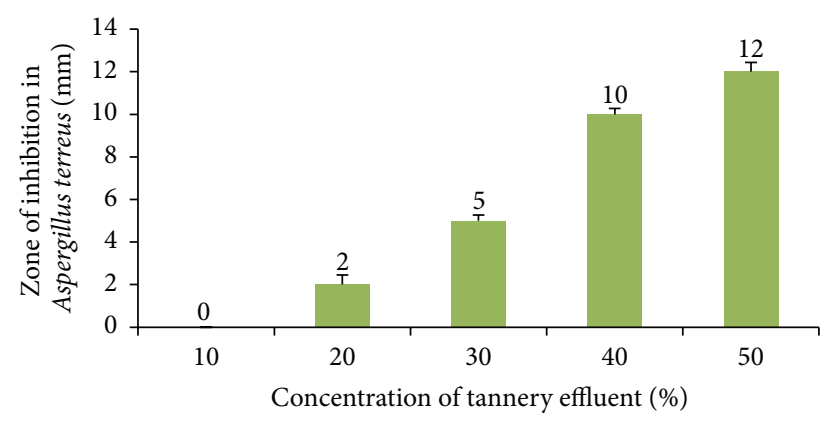

(c)

FIGURE 3: Effect of tannery effluent on ecofriendly microorganisms. (a) Zone of inhibition in Bacillus thuringiensis (mm). (b) Zone of inhibition in Rhizobium etli ( $\mathrm{mm})$. (c) Zone of inhibition in Aspergillus terreus ( $\mathrm{mm}$ ).

Allium cepa exposed to TE was found to be $7.79 \%$ which is almost similar to the findings of Gupta et al. (2011) [40]. The inhibition of root growth may be due to suppression of root cell division/root elongation or the extension of cell cycle in the roots [41]. It was also observed that the TE treatment resulted in a significant decline of frond number, chlorophyll, and protein content in Lemna minor. Major toxicity of TE in plant can be observed with respect to photosynthetic pigment, photosynthesis, and protein content [42]. In our study, the TE treatment showed a significant decrease in protein and pigment contents. The protein and pigment content of Lemna minor gradually decreased with an increasing concentration of TE. It was already reported that the presence of heavy metals results in chlorosis, necrosis, and change in the concentration of essential minerals in plants $[43,44]$ and in cyanobacteria [45]. Reduction in photosynthesis may result from the stomatal closure and alteration in the ultrastructure of chloroplast. High concentration of cobalt, chromium, and copper greatly affect the concentration of iron, chlorophyll "a" and chlorophyll "b", protein, and catalase activity in plants [23]. Chromium is known as the toxic, mutagenic, carcinogenic, and teratogenic component of tannery effluent and it is a strong oxidizing agent that causes severe damage to cell membranes [46]. Chromium toxicity can reduce the size of the epidermal layer of the antenna complex in chloroplast which can ultimately decrease the chlorophyll a content [44]. It can also lead to impairment and denaturation of the proteins of the outermost part of antenna reducing the chlorophyll b content of the plant. Under the chromium stress, there can be inactivation of enzymes which are involved in the biosynthesis pathway of chlorophyll, ultimately reducing the chlorophyll content as a whole [47].

The TE showed toxicity to the tested cyanobacteria Nostoc muscorum by reducing the total chlorophyll content. The toxicity might be due to the presence of high level of chromium in TE. Cr (VI) reduces the quantum yield of PSII reaction centre and thus affects the chlorophyll content. High chromium content can also lead to DNA damage and may lead to the death of algal cells. An increase in TE concentration caused a significant decrease in the cell density and cell number. The exposure to tannery effluent in plants affects their metabolic process in several ways including reduction in growth, photosynthesis, chlorophyll content, and degradation of chloroplast and mitochondria.

The tannery effluent was found to be toxic to human leukocyte. It hinders the cytokinesis of the cells and mitotic index is expected to reduce considerably. In this study, even the lower concentrations of TE induced the potential toxicity to healthy human leukocytes. Cell counts of the leukocyte were reduced to almost $50 \%$ at $20 \%$ TE (Table 6). The TE interferes with the normal mitotic division, inducing cell death. In addition, tannery effluent was also found to induce chromosomal aberrations at all the tested concentrations. These results can be explained by the condition that TE might also interfere with the normal replication process and may also induce mutations that could be temporary or permanent [48]. This study focused further on effect of tannery in inducing micronucleus formation in the healthy leukocyte. Micronucleus was observed in cells exposed to $10 \%$ and $20 \%$ of TE. Since the presence of micronucleus indicates cellular damage, the TE can be considered toxic to the healthy human 
leukocyte even at small concentrations. The tannery effluent was also found to be toxic to red blood cells (erythrocytes) at the minimum concentration of 5\%. The hemolysis was found to be dose dependent and cause $50 \%$ cell death at $10 \% \mathrm{TE}$. This result may be explained on the basis of the studied toxicity of chromium to the cells that forms the main constituent of tannery effluent. This proves that exposure of RBCs to even small concentration of TE can lead to lethal effects [49].

Our study revealed that the TE was highly toxic to the tested microorganism (Bacillus thuringiensis, Rhizobium etli, and Aspergillus terreus). Growth of all the organisms was inhibited by TE even at lower concentrations (5\%). The toxicity may be due to the heavy metals present in the tannery effluent inhibiting the growth and activity of the natural bacterial populations. It may be due the complex-formation of heavy metals with organic compounds [50,51] and heavy metals accumulation [52].

\section{Conclusions}

From the result obtained, it can be concluded that the physicochemical parameters of the TE, namely, dissolved oxygen and total dissolved solids, COD, BOD, nickel, magnesium, chloride, potassium, nitrite, sulphur, and chromium, were found to be much above the permissible limits prescribed by USEPA. The discharged TE into the Palar River, Ambur, is highly toxic to microorganisms, plants, and human blood cells, as it drastically affected the growth of microorganisms, root, protein, and chlorophyll content of the plants and chromosomes of human blood cells. Therefore, it is suggested that the release of effluent from tannery industries should be done after proper treatment and recycled to the maximum possible level and disposal into water resources should be minimised. Since the experimental conditions were carried out using diluted form of effluent, it can be interpreted that the crude effluent is highly toxic. It can also act as major water and soil pollutant in the respective area which may drastically affect ecofriendly microorganisms, plants, and also human beings.

\section{Conflict of Interests}

The authors declare that there is no conflict of interests regarding the publication of this paper.

\section{Acknowledgments}

The study was supported by the institutional grant and the authors thank the management of VIT University for providing the necessary facilities.

\section{References}

[1] A. Santovito, P. Cervella, and M. Delpero, "Micronucleus frequency in human lymphocytes after exposure to diphenylamine in vitro," Mutation Research/Genetic Toxicology and Environmental Mutagenesis, vol. 747, no. 1, pp. 135-137, 2012.

[2] N. Manivasagam, "Industrial effluents origin, characteristic effects, analysis and treatment Kovaipudur, India," Shakti Publication, vol. 42, 1987.
[3] R. S. Sreenivasan and P. K. Moorthy, "Biochemical stress of chromium in tannery effluents on the fresh water fish Tilapia mossambica (Pisces)," International Journal of Biological and Medical Research, vol. 2, no. 3, pp. 784-788, 2011.

[4] K. Gupta, S. Gaumat, and K. Mishra, "Studies on phytogenotoxic assessment of tannery effluent and chromium on Allium cepa," Journal of Environmental Biology, vol. 33, no. 3, pp. 557-563, 2012.

[5] L. Kennedy, "Cooperating for survival: tannery pollution and joint action in the Palar Valley (India)," World Development, vol. 27, no. 9, pp. 1673-1691, 1999.

[6] G. Abdul, S. Mansour, A. Okab, and R. Ahmed, "Exploiting of the phenoxazine as first-ever use ligand in rapid spectrophotometric methods for the determination of chromium (VI) in environmental samples," Analele Universitatii "Ovidius" Constanta-Seria Chimie, vol. 23, no. 2, pp. 180-186, 2012.

[7] W. Hou, X. Chen, G. Song, Q. Wang, and C. Chi Chang, "Effects of copper and cadmium on heavy metal polluted waterbody restoration by duckweed (Lemna minor)," Plant Physiology and Biochemistry, vol. 45, no. 1, pp. 62-69, 2007.

[8] A. Zayed, S. Gowthaman, and N. Terry, "Phytoaccumulation of trace elements by wetland plants: I. Duckweed," Journal of Environmental Quality, vol. 27, no. 3, pp. 715-721, 1998.

[9] T. O. Siyanbola, K. O. Ajanaku, O. O. James, J. A. O. Olugbuyiro, and J. O. Adekoya, "Physico-chemical characteristics of industrial effluents in Lagos state, Nigeria," Global Journal of Pure and Applied Sciences, vol. 1, pp. 49-54, 2011.

[10] V. Velma, S. S. Vutukuru, and P. B. Tchounwou, "Ecotoxicology of hexavalent chromium in freshwater fish: a critical review," Reviews on Environmental Health, vol. 24, no. 2, pp. 129-145, 2009.

[11] M. E. Lewis, Field Measurements, US Geological Survey, Reston, Va, USA, 2006.

[12] S. T. Matsumoto, M. S. Mantovani, M. I. A. Malaguttii, A. L. Dias, I. C. Fonseca, and M. A. Marin-Morales, "Genotoxicity and mutagenicity of water contaminated with tannery effluents as evaluated by the micronucleus test and comet assay using the fish Oreochromis niloticus and chromosome aberrations in onion root-tips," Genetics and Molecular Biology, vol. 29, no. 1, pp. 148-158, 2006.

[13] A. I. Vogel, Text-Book of Quantitative Inorganic Analysis Including Elementary Instrumental Analysis, Longmans, 1961.

[14] R. Michalski, "Ion chromatography as a reference method for determination of inorganic ions in water and wastewater," Critical Reviews in Analytical Chemistry, vol. 36, no. 2, pp. 107127, 2006.

[15] M. M. Altaf, F. Masood, and A. Malik, "Impact of longterm application of treated tannery effluents on the emergence of resistance traits in Rhizobium sp. isolated from Trifolium alexandrinum," Turkish Journal of Biology, vol. 32, no. 1, pp. 1-8, 2008.

[16] A. Bravo and J. Mora, "Ammonium assimilation in Rhizobium phaseoli by the glutamine synthetase-glutamate synthase pathway," Journal of Bacteriology, vol. 170, no. 2, pp. 980-984, 1988.

[17] A. W. Bauer, D. M. Perry, and W. M. M. Kirby, "Single-disk antibiotic-sensitivity testing of staphylococci: an analysis of technique and results," AMA Archives of Internal Medicine, vol. 104, no. 2, pp. 208-216, 1959.

[18] J. M. Andrews, "Determination of minimum inhibitory concentrations," Journal of Antimicrobial Chemotherapy, vol. 48, no. 1 , pp. 5-16, 2001. 
[19] G. C. Gerloff, G. P. Fitzgerald, and F. Skoog, "The isolation, purification, and culture of blue-green algae," American Journal of Botany, vol. 37, no. 3, pp. 216-218, 1950.

[20] D. Rai, L. E. Eary, and J. M. Zachara, "Environmental chemistry of chromium," Science of the Total Environment, vol. 86, no. 1-2, pp. 15-23, 1989.

[21] O. H. Lowry, N. J. Rosebrough, A. L. Farr, and R. J. Randall, "Protein measurement with the Folin phenol reagent," The Journal of Biological Chemistry, vol. 193, no. 1, pp. 265-275, 1951.

[22] V. K. Singh and J. Singh, "Toxicity of industrial wastewater to the aquatic plant Lemna minor L.," Journal of Environmental Biology, vol. 27, no. 2, pp. 385-390, 2006.

[23] "Allium Cepa and Lemna Minor Biology Essay," Essays, UK, http://www.ukessays.com/essays/biology/allium-cepa-and-lemna-minor-biology-essay.php?cref=1.

[24] D. I. Arnon, "Copper enzymes in isolated chloroplasts. Polyphenoloxidase in Beta vulgaris," Plant Physiology, vol. 24, no. 1, pp. $1-15,1949$.

[25] S. H. H. Swierenga, J. A. Heddle, E. A. Sigal et al., "Recommended protocols based on a survey of current practice in genotoxicity testing laboratories, IV. Chromosome aberration and sister-chromatid exchange in Chinese hamster ovary, V79 Chinese hamster lung and human lymphocyte cultures," Mutation Research/Fundamental and Molecular Mechanisms of Mutagenesis, vol. 246, no. 2, pp. 301-322, 1991.

[26] L. Donbak, E. Rencuzogullari, A. Yavuz, and M. Topaktas, "The genotoxic risk of underground coal miners from Turkey," Mutation Research-Genetic Toxicology and Environmental Mutagenesis, vol. 588, no. 2, pp. 82-87, 2005.

[27] G. Speit and S. Haupter, "On the mechanism of differential Giemsa staining of bromodeoxyuridine-substituted chromosomes," Human Genetics, vol. 70, no. 2, pp. 126-129, 1985.

[28] M. Fenech, “The in vitro micronucleus technique," Mutation Research/Fundamental and Molecular Mechanisms of Mutagenesis, vol. 455, no. 1-2, pp. 81-95, 2000.

[29] M. Fenech and A. A. Morley, "Measurement of micronuclei in lymphocytes," Mutation Research/Environmental Mutagenesis and Related Subjects, vol. 147, no. 1-2, pp. 29-36, 1985.

[30] P. I. Countryman and J. A. Heddle, "The production of micronuclei from chromosome aberrations in irradiated cultures of human lymphocytes," Mutation Research/Fundamental and Molecular Mechanisms of Mutagenesis, vol. 41, no. 2-3, pp. 321-331, 1976.

[31] K. Suthindhiran and K. Kannabiran, "Hemolytic activity of Streptomyces VITSDK1 spp. isolated from marine sediments in Southern India," Journal of Medical Mycology, vol. 19, no. 2, pp. 77-86, 2009.

[32] D. Malagoli, "A full-length protocol to test hemolytic activity of palytoxin on human erythrocytes," Invertebrate Survival Journal, vol. 4, no. 2, pp. 92-94, 2007.

[33] S. M. Galloway, M. J. Aardema, M. Ishidate Jr. et al., "Report from working group on in vitro tests for chromosomal aberrations," Mutation Research/Environmental Mutagenesis and Related Subjects, vol. 312, no. 3, pp. 241-261, 1994.

[34] USEPA, “Guidelines for Water Reuse," Tech. Rep. No. EPA/625/ R-04/108, Environmental Protection Agency (Municipal Support Division Office of Wastewater Management), Washington, DC, USA, 2004.

[35] Agency NFEP, Guidelines and Standards for Environmental Pollution Control in Nigeria, Federal Environmental Protection Agency (FEPA), 1991.
[36] UNIDO, United Nations Industrial Development Organization, Cost of Tanned Waste Treatment, 15th Session of the Leather and Leather Products Industry Panel, Leon, Mexico, 2005.

[37] I. Bisschops and H. Spanjers, "Literature review on textile wastewater characterisation," Environmental Technology, vol. 24, no. 11, pp. 1399-1411, 2003.

[38] A. B. Rabah and M. L. Ibrahim, "Physico-chemical and microbiological characterization of soils laden with tannery effluents in Sokoto, Nigeria," Nigerian Journal of Basic and Applied Sciences, vol. 18, no. 1, pp. 65-71, 2010.

[39] J. C. Akan, E. A. Moses, V. O. Ogugbuaja, and J. Abah, "Assessment of tannery industrial effluents from Kano metropolis, Kano State, Nigeria," Journal of Applied Sciences, vol. 7, no. 19, pp. 2788-2793, 2007.

[40] K. Gupta, S. Gaumat, and K. Mishra, "Chromium accumulation in submerged aquatic plants treated with tannery effluent at Kanpur, India," Journal of Environmental Biology, vol. 32, no. 5, pp. 591-597, 2011.

[41] P. U. Sundaramoorthy and L. K. Kunchithapatam, "Effect of tannery effluent on germination and seedling growth of groundnut varieties," Journal of EcoBiology, vol. 13, pp. 3-8, 2001.

[42] H. Diwan, A. Ahmad, and M. Iqbal, "Chromium-induced alterations in photosynthesis and associated attributes in Indian mustard," Journal of Environmental Biology, vol. 33, no. 2, pp. 239-244, 2012.

[43] M. Tkalec, T. Prebeg, V. Roje, B. Pevalek-Kozlina, and N. Ljubešić, "Cadmium-induced responses in duckweed Lemna minor L.," Acta Physiologiae Plantarum, vol. 30, no. 6, pp. 881890, 2008.

[44] A. K. Shanker, C. Cervantes, H. Loza-Tavera, and S. Avudainayagam, "Chromium toxicity in plants," Environment International, vol. 31, no. 5, pp. 739-753, 2005.

[45] A. Ghani, "Effect of chromium toxicity on growth, chlorophyll and some mineral nutrients of Brassica juncea L," Egyptian Academic Journal of Biological Sciences, vol. 2, no. 1, pp. 9-15, 2011.

[46] A. A. Belay, "Impacts of chromium from tannery effluent and evaluation of alternative treatment options," Journal of Environmental Protection, vol. 1, no. 1, pp. 53-58, 2010.

[47] N. Lal, "Biochemical alterations due to acute tannery effluent toxicity in Lemna minor L.," Journal of Phytology, vol. 1, no. 6, pp. 361-368, 2009.

[48] A. Asfaw, M. Sime, and F. Itanna, "Determining the effect of tannery effluent on seeds germination of some vegetables in Ejersa area of East Shoa, Ethiopia," International Journal of Scientific and Research Publications, vol. 2, no. 12, pp. 1-10, 2012.

[49] F. Zölzer, Z. Hon, Z. Freitinger Skalická et al., "Persistence of genetic damage in lymphocytes from former uranium miners," Cytogenetic and Genome Research, vol. 136, no. 4, pp. 288-294, 2012.

[50] J. F. Benazir, R. Suganthi, D. Rajvel, M. P. Pooja, and B. Mathithumilan, "Bioremediation of chromium in tannery effluent by microbial consortia," African Journal of Biotechnology, vol. 9, no. 21, pp. 3140-3143, 2010.

[51] P. Beneš, E. T. Gjessing, and E. Steinnes, "Interactions between humus and trace elements in fresh water," Water Research, vol. 10, no. 8, pp. 711-716, 1976.

[52] C. Cervantes, J. Campos-García, S. Devars et al., "Interactions of chromium with microorganisms and plants," FEMS Microbiology Reviews, vol. 25, no. 3, pp. 335-347, 2001. 

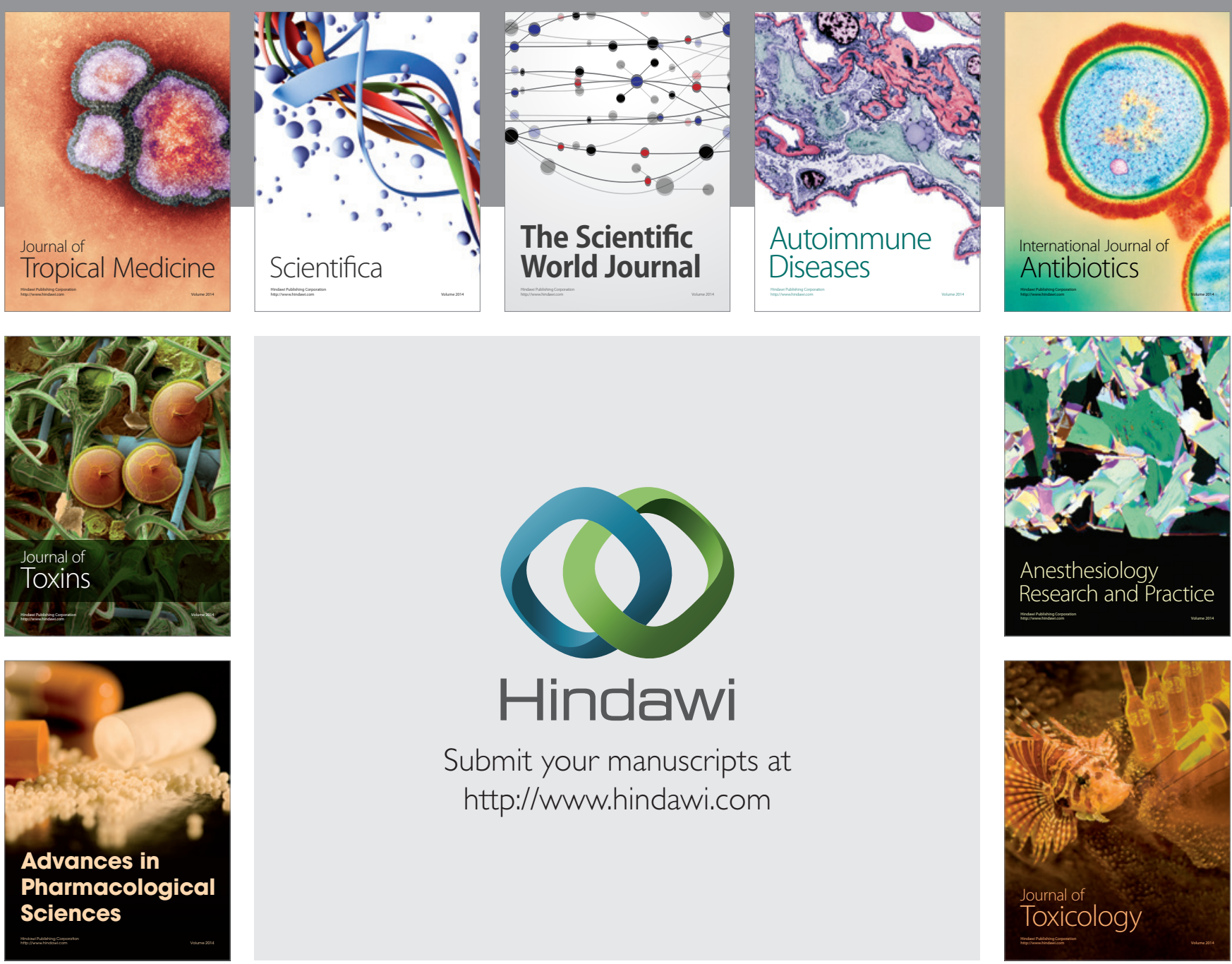

\section{Hindawi}

Submit your manuscripts at

http://www.hindawi.com
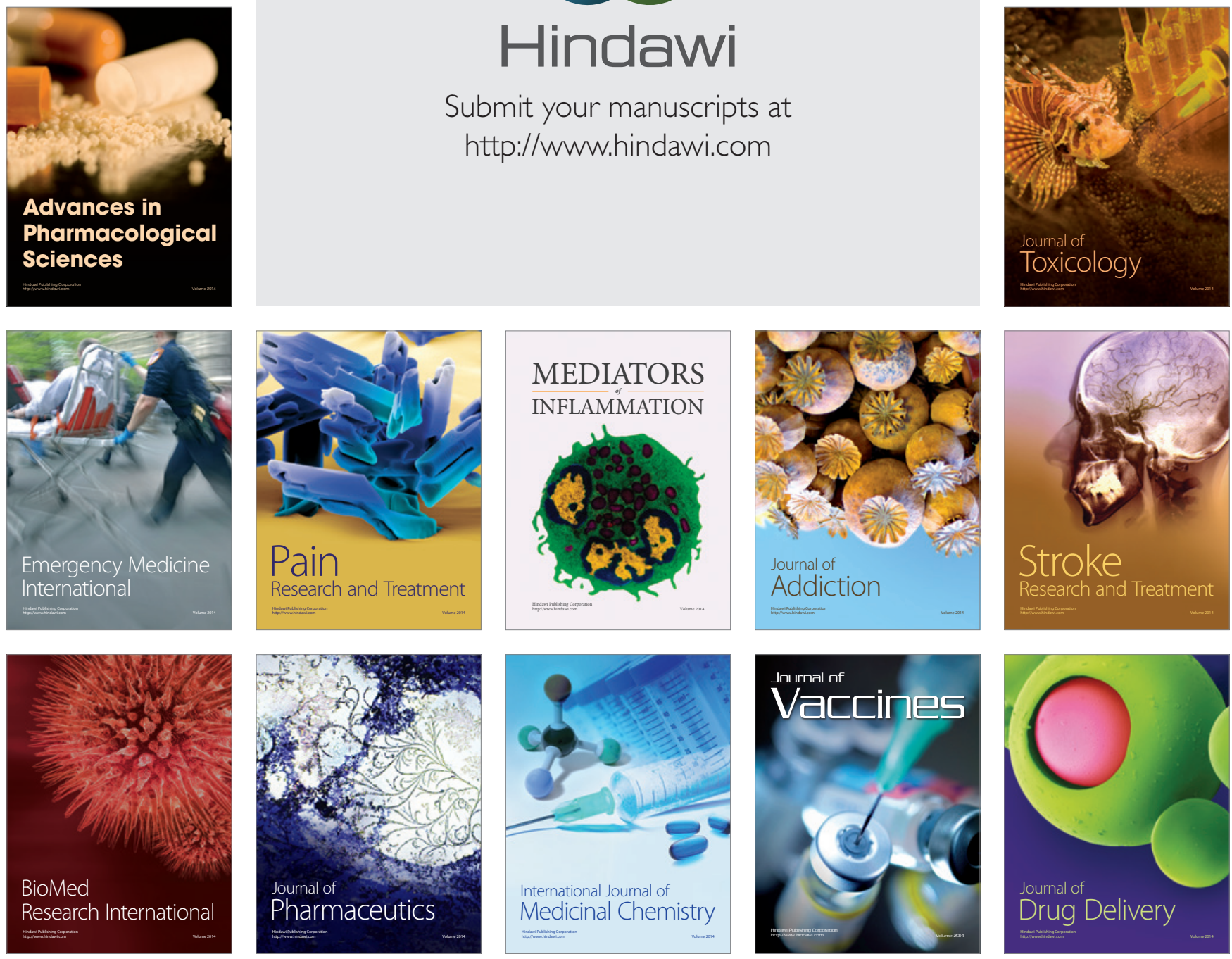